\title{
Child health care system in Ukraine
}

\author{
Andrii Loboda, (1) Olexander Smiyan, (10) Serhii Popov, (1) Victoriia Petrashenko, (ㄱ) Ihor Zaitsev, \\ Olena Redko, (1) Mykola Zahorodnii, (1) Svitlana Kasyan
}

Department of Pediatrics, Medical Institute, Sumy State University, Sumy, Ukraine

\begin{abstract}
The child healthcare system in Ukraine is coordinated and managed at a central level by the Ministry of Health and at a local level by the regional health authorities. The Ministry of Health has executive the power for the implementation of state health policies and controls and manages state-owned health facilities. The system of public funding for the pediatric healthcare system is divided into two sources: central and local. Primary healthcare is organized by the National Health Service of Ukraine. Secondary level healthcare is mostly organized by the Ministry of Health, which gives money for hospitals and medical centers. Since 2014, due to reform and decentralization in Ukraine, local, regional, and city administrations received money from the Ukrainian government for the formation of decentralized budgets.
\end{abstract}

Keywords: Healthcare, neonatal, vaccinations

\section{Introduction}

Ukraine has a population of approximately 42.39 million people and a birth rate of $8.4 / 1000$. Ukraine is a lower-middle income country with a gross domestic product (GDP) per capita of 2.64 US dollars (1). The health system is funded through the Ministry of Health of Ukraine, the National Health Service of Ukraine, local administrations (regional, city), and amalgamated community funds (2). Ukrainian children are guaranteed access to universal primary, secondary (polyclinic and hospital), and specialist tertiary care provided by a network of health institutions. The indicators of the level of health in a country (neonatal, infant, under-five mortality) have improved over the last decade. Major problems that remain include the high prevalence of tuberculosis, HIV-infection, and the low percentage of fully vaccinated children.

\section{Geography and history}

Ukraine is situated in Eastern Europe, bordered by the Russian Federation to the east and northeast, Belarus to the northwest, Poland, Slovakia and Hungary to the west, Romania and Moldova to the southwest, and the Black Sea and Sea of Azov to the south and southeast. It has an area of $603,628 \mathrm{~km}^{2}$, making it the largest country entirely within Europe.
The medieval state of Kievan Rus was established in the $9^{\text {th }}$ century as the first historically recorded East Slavic state. Unfortunately, Kievan Rus disintegrated in the $12^{\text {th }}$ century and by the middle of the $14^{\text {th }}$ century, Ukrainian territories were under the rule of three external powersthe Golden Horde, the Grand Duchy of Lithuania, and the Kingdom of Poland. During the $17^{\text {th }}$ and $18^{\text {th }}$ centuries, a Cossack republic emerged and prospered, but its territory was eventually split between the Kingdom of Poland and the Russian Empire. By the $19^{\text {th }}$ century, the largest part of Ukraine was integrated into the Russian Empire, with the rest under Austro-Hungarian control.

The Independent Ukrainian People's Republic was founded in 1917. Then, Soviet intervention resulted in the establishment of Ukrainian Soviet Socialist Republic (Ukrainian SSR) and Soviet rule for more than 70 years. After the 1939 invasion of Poland by Nazi Germany and the Soviet Union, the Ukrainian SSR's territory was enlarged westward. In 1954, it expanded to the south with the Crimea.

Ukraine became independent again when the Soviet Union dissolved in 1991. For more than 20 years, Ukraine has suffered from a socioeconomic crisis related to the transition to a market-style economy. Internal instability and

Cite this article as: Loboda A, Smiyan O, Popov S, et al. Child health care system in Ukraine. Turk Pediatri Ars 2020; 55(Suppl 1): S98-S104. 
Table 1. Sociodemographic characteristics of Ukraine

\begin{tabular}{lcccccc}
\hline & $\mathbf{1 9 9 1}$ & $\mathbf{1 9 9 5}$ & $\mathbf{2 0 0 0}$ & $\mathbf{2 0 0 5}$ & $\mathbf{2 0 1 0}$ & $\mathbf{2 0 1 7}$ \\
\hline Total population x10 & 51.94 & 51.73 & 49.43 & 47.28 & 45.96 & 42.39 \\
Annual number of births & 630.813 & 492.861 & 385.126 & 426.085 & 497.689 & 363.990 \\
Annual number of deaths & 669.960 & 792.587 & 758.082 & 781.964 & 698.235 & 574.123 \\
Annual growth rate of population & -39.147 & -299.726 & -372.956 & -355.879 & -200.546 & -210.136 \\
Birth rate (per 1000 people) & 12.1 & 9.6 & 7.8 & 9.0 & 10.8 & 8.4 \\
Death rate (per 1000 people) & 12.9 & 15.4 & 15.4 & 16.6 & 15.2 & 13.4 \\
Annual growth rate of population (per 1000 people) & -0.8 & -5.8 & -7.6 & -7.6 & -4.4 & -5.0 \\
& & & & & & \\
\hline
\end{tabular}

a long-term territorial dispute with Russia over the Crimean Peninsula caused annexation of Crimea by the Russian Federation in 2014. Since April 2014, Ukraine has been in continuous conflict in the Donetsk and Luhansk regions against terrorists, which are supported by Russian troops.

\section{Sociodemographic situation}

Ukraine has a population of approximately 42.39 million people, a birth rate of $8.4 / 1000$, and life expectancy at birth is 71 years (2015) (1).

Dramatically worsening life conditions, war conflict in the East of the country, and massive emigration have caused a negative annual growth rate of the population. This is why the country's population decreased from 51.94 million in 1991 to 42.39 million in 2017. The annual number of births decreased from 630,813 to 363,990 (Table 1) (2). The percentage of the population aged 0-14 years decreased from $21.6 \%$ in 1989 to $15.76 \%$ in 2017 . The fertility rate in Ukraine is fairly low - 1.54 children born per woman, indicating that the country occupies $191^{\text {th }}$ place in the world for birth rate (3).

During the last decade the urban population increased to $69.4 \%$ of the total population. Despite migration to urban areas, the number of unemployed youth aged 15-24 years increased to $22.4 \%$ ( $56^{\text {th }}$ place in the world) (3).

In 2017, Ukraine's GDP per capita of 2.640 US dollars and occupied $127^{\text {th }}$ place in the world (4). That is why Ukraine represents as a lower-middle income country.

The main ethnic group in Ukraine is Ukrainian (77.8\% of total population). Other ethnic groups include Russian (17.3\%), Belarusian (0.6\%), Moldovan (0.5\%), Crimean Ta$\operatorname{tar}(0.5 \%)$, Bulgarian (0.4\%) (3).

\section{Pediatric healthcare system and current problems}

The pediatric healthcare system in Ukraine is coordinated and managed at a central level by the Ministry of
Health and at a local level by the regional health authorities. The Ministry of Health has the executive power for the implementation of state health policies and controls and manages state-owned health facilities.

The funding of the pediatric healthcare system is divided into two sources: central and local. Central: for primary healthcare managed by the National Health Service of Ukraine (established in March 2018). Secondary level of healthcare is managed mainly by the Ministry of Health which gives money to hospitals and medical centers.

Local: Since 2014 due to decentralization in Ukraine, local administrations (regional, city) received money from the Ukrainian government for decentralized budgets. Part of healthcare needs (including pediatrics) is covered by this source; a second important resource is from amalgamated community funds.

The role of voluntary health insurance is insignificant, as few people can afford the premiums. Less than $5 \%$ of Ukrainians are covered by voluntary medical insurance (5).

The establishment of the National Health Service of Ukraine (NHSU) was one of the key factors in the reform of the healthcare system. The NHSU implements the national policy relating to government financial guarantees for medical services for the population and fulfills the functions of the national medical services and medicines customer under the program of medical guarantees.

Ukraine has a combined system of primary care for children (approximately $50 \%$ children served by pediatricians and $50 \%$ by family physicians). Pediatricians and family physicians follow children from birth until the age of 18 years. A normal patient number for a healthcare specialist is approximately 800 .

Nowadays, more than 600 primary healthcare providers (which include non-profit enterprises, private providers 
and physicians-entrepreneurs) have signed agreements with the NHSU. Since the end of 2018, all primary healthcare providers have to register with the eHealth system, provide services in full compliance with the approved procedure and requirements, and sign an agreement with the NHSU. Commencing in 2019, 100\% of payments for the actual primary care services rendered to patients is made under the NHSU-funded contract-based age-adjusted capitation model (6).

Departments of territorial polyclinics and the polyclinic departments of hospitals provide outpatient pediatric services at secondary level. Sick children are referred to the secondary level by primary healthcare providers, both pediatricians and family physicians. A network of regional and city hospitals provides inpatient care at the secondary level.

Once a patient is hospitalized and needs a higher level of specialty care within the hospital, they may be referred to tertiary care. There are two main centers of tertiary care in the country: The National Children Specialized Hospital «OHMATDYT», and the Institute of Pediatrics, Obstetrics and Gynecology of National Academy of Medical Science of Ukraine.

Ukraine has supported the introduction of the International Code of Marketing of Breast-Milk Substitutes and the implementation of the Expanded Baby-Friendly Hospital Initiative (BFHI) since 2006. Currently, 220 Ukrainian healthcare facilities have received this title (7). Due to this program, the percentage of children exclusively breastfed in the first six months is $54.9 \%$ (2014). The same indicator in $\mathrm{BFH}$ to $65.9 \%$ (8).

National research conducted in 2003 by the Ministry of Health with support from the United Nations Children's Fund (UNICEF) and by the Centers for Disease Control and Prevention (CDC, USA) confirmed mild iodine deficiency in the entire population of Ukraine. Eighty percent of children are born and grow in conditions of iodine deficiency without consuming the necessary amount of iodine with food. Eliminating iodine deficiency disorders by means of universal salt iodization, the most effective method, remains an urgent issue in Ukraine. The overall iodized salt consumption throughout the country was only $20.7 \%(9)$.

The infant mortality and under-five mortality rates as indicators of the level of health in the country decreased during the last decade (Table 2) $(10,11)$.

Ukrainian neonatologists provide care in compliance with the world's best standards and international proto-
Table 2. Infant mortality and under-five mortality rate in Ukraine

\begin{tabular}{lcccccc}
\hline & 2007 & 2009 & 2011 & 2013 & 2016 & $\mathbf{2 0 1 7}$ \\
\hline Infant mortality & 9.5 & 8.98 & 8.54 & 8.24 & 8.0 & 7.8 \\
Under-five mortality & 13.4 & 12.3 & 11.2 & 10.2 & 9.1 & 8.8 \\
\hline
\end{tabular}

Table 3. Neonatal mortality rate in Ukraine

200720092011201320162017

\begin{tabular}{lllllll}
\hline Infant mortality & 7.9 & 7.3 & 6.6 & 6.0 & 5.4 & 5.2 \\
\hline
\end{tabular}

cols. This policy resulted in the improved quality of neonatal care during recent years (Table 3) (12).

National newborn screening programs test babies for inherited disorders that are often not apparent at birth. Such disorders include congenital hypothyroidism, phenylketonuria, congenital adrenal hyperplasia and cystic fibrosis. Neonatal screening begins with a heel prick that is done within 24-48 hours of a baby's birth. A health-care professional collects blood from the baby's heel onto a filter-paper card. This card is sent to a newborn screening laboratory for testing. During 2018, state program for neonatal screening involved more than 122,000 newborns.

The next two steps required improving the quality of neonatal care at healthcare facilities nationwide through the provision of modern equipment to regional perinatal centers, and the establishment of training centers for professional development of Ukrainian neonatologists.

Ukraine has made a number of commitments to improving the wellbeing of children, particularly by signing and ratifying: (1) The UN Convention of the Rights of the Child (CRC) in 1991; (2) the Optional Protocol to the UN CRC on the Sale of Children, Child Prostitution and Child Pornography in 2003; (3) the Optional Protocol to the UN CRC on the Involvement of Children in Armed Conflict in 2004; (4) The UN Convention against Trans-national Organized Crime in February 2004.

The adoption of the National Plan of Action (NPA) for Children (2010-2016) marked progress towards developing a strategic and comprehensive legal framework for the implementation of child rights. The NPA pays particular attention to equity and protection of the most disadvantaged children and contains provisions for equitable access to quality healthcare and education regardless of children's social and economic status (13).

Current issues in pediatric healthcare and child rights are listed in Table $4(9,14,15)$ : 
Table 4. Current issues in pediatric healthcare and children in Ukraine

- The quality of primary medical care available to mothers and babies is low and access to such services, especially for socially vulnerable groups and the rural population, is limited;

- Absence of national standards for child development in Ukraine;

- Insufficient access to a children's hotline that provides information, psychological, and legal assistance to children;

- The number of registered internally displaced children reached 215,464 (January 2016);

- Lack of providing primary medical services and creating the conditions for healthy and full child development in at Chernobyl-affected areas

- In 2019 there have been at least 36 verified attacks on schools in conflict region settlements within $15 \mathrm{~km}$ of the contact line. More than 400,000 children live with psychological wounds and need ongoing support to address the emotional trauma of growing up in a prolonged conflict.

\section{Medical education (pediatrics aspects)}

There are 23 higher education institutions in Ukraine, which provide medical education in specialties "Medicine" and "Pediatrics": 14 are structures of the Ministry of Health of Ukraine, three are medical faculties (medical institutes) of the Ministry of Education and Science of Ukraine, and six are private institutions. Approximately 7000 students graduated in 2018 as specialists and received diplomas.

The undergraduate master's course in "Pediatrics" comprises six academic years. The syllabuses of fundamental sciences are very close to those of the "Medicine" course; however, particular attention is paid to child health.

The students receive general biologic and medical knowledge in the first courses, an introduction to pediatrics begins in the $3^{\text {rd }}$ year. During their $4^{\text {th }}$ year, students are taught the pathology of childhood, pulmonology, allergology, cardio-rheumatology, gastroenterology and nephrology. Our $5^{\text {th }}$ year includes neonatology, endocrinology, hematology and childhood infectious disease. Pediatric education in the $6^{\text {th }}$ year includes ambulatory care, principles of differential diagnosis, emergency and intensive care in pediatrics. From the $3^{\text {rd }}$ to the $6^{\text {th }}$ years, special focus is paid to studying palliative care, ethical, and professional problems.

A required component of the curriculum is internal or international academic mobility (i.e. Erasmus+), which stimulates knowledge exchange and creates new professional contact network in Ukraine and abroad.

Those who successfully complete their education ad acquire the diploma can continue to study in internships in pediatrics and be involved in research work. Only after completing the internship can the physician proceed to independent work as a pediatrician and to subsequent fellowship in pediatric subspecialties, such as pediatric cardiology, nephrology, and gastroenterology.
The training of pediatricians is under state control. For the past 20 years, the of Ministry of Health of Ukraine has assessed the level of fundamental and clinical knowledge of medical students in the $3^{\text {rd }}$ and $6^{\text {th }}$ years, respectively, with help of special exams "Step-1" and "Step-2". Only students who successfully pass exam "Step-1" can continue their education to the fourth course, and only student who successfully pass exam "Step-2" can receive a diploma. A third assessment is made during internship in pediatrics. Only a doctor who successfully passes exam "Step-3" can receive a pediatrician certificate.

The continuous medical education system of Ukraine consists of two parts: national and international. Every year, pediatricians have to pass the official training courses of the Faculty of Post-Graduate Education of Medical University and take part in national conferences, congresses, and write articles or recommendations. Each type of activity is given points (credits) and the minimum number of points necessary for attestation is 50 . The international component of continuous medical education is by participation in the activities of international organizations (UNICEF, Amer-ican Austrian Foundation, and Medscape) such as clinical observerships, fellowships or medical online education programs, which receive CME credits.

\section{HIV-infection among children in Ukraine}

Ukraine was one of the countries that initiated the UN Special Session on HIV/AIDS (UNGASS) in 2001. However, our country has the second-largest HIV epidemic in Eastern Europe and Central Asia, accounting for $9 \%$ of new infections in the region in 2016. It is now estimated that approximately $73 \%$ of new cases are the result of sexual transmission (16). This level may be the result a lack of knowledge regarding HIV prevention. In 2018, knowledge of HIV prevention among young people (aged 15-24 years) in Ukraine was low at 23\%. Young men were marginally more knowledgeable than young women $(25 \%$, compared with 21\%) (17). 
Table 5. Ukraine National Vaccination Schedule issued by The Ministry of Health (2018)

\begin{tabular}{|c|c|c|c|c|c|c|c|c|c|c|c|}
\hline Type of vaccine & $\begin{array}{c}\text { at } \\
\text { birth* }\end{array}$ & $\begin{array}{c}\text { 3-4 } \\
\text { days }\end{array}$ & $\begin{array}{c}2 \\
\text { months }\end{array}$ & $\begin{array}{c}4 \\
\text { months }\end{array}$ & $\begin{array}{c}6 \\
\text { months }\end{array}$ & $\begin{array}{c}12 \\
\text { months }\end{array}$ & $\begin{array}{c}18^{\mathrm{h}} \\
\text { months }\end{array}$ & $\begin{array}{c}6 \\
\text { years }\end{array}$ & $\begin{array}{c}14 \\
\text { years }\end{array}$ & $\begin{array}{c}16 \\
\text { years }\end{array}$ & $\begin{array}{c}\text { any } 10 \\
\text { years }\end{array}$ \\
\hline Hepatitis B & • & & • & & - & & & & & & \\
\hline Tuberculosis & & $\bullet$ & & & & & & & & & \\
\hline Measles, mumps, rubella & & & & & & - & & - & & & \\
\hline Diphtheria, tetanus & & & • & • & - & & • & - & - & & - \\
\hline Whooping cough (pertussis) & & & • & • & • & & • & & & & \\
\hline Poliomyelitis & & & • & $\bullet$ & • & & • & • & • & & \\
\hline $\begin{array}{l}\text { Haemophilus influenzae } \\
\text { type B (HIB) }\end{array}$ & & & $\bullet$ & $\bullet$ & & $\bullet$ & & & & & \\
\hline
\end{tabular}

There has been an almost eight-fold reduction in the rate of mother-to-child transmission of HIV in Ukraine since 2001: from $27.8 \%$ in 2001 to $3.7 \%$ in 2015. In 2018, 95\% of pregnant women living with HIV were receiving antiretroviral therapy as part of preventing mother-to-child transmission and less than 500 children became HIV positive due to mother-to-child transmission. The number of HIV-exposed children who are uninfected increased from 1990 to 2018 (in 2018 - 43,000 per year). The diagnosis of HIV in early infancy was 65\% (17) in 2018 (Fig. 1).

The largest number of HIV infected children live in the regions with high HIV prevalence where the epidemic process is fuelled by the transmission of the virus in most at-risk populations such as injecting drug users. In 2017, the number of children aged 0 to 14 years with HIV was $5000,54 \%$ of whom were receiving antiretroviral treatment (2702 persons). Adherence to treatment is relatively high. In 2017, $88 \%$ of children were known to be on antiretroviral treatment 12 months after starting it $(16,17)$.

\section{Vaccination in Ukraine}

The government immunization program includes vaccination against 10 main infections (tuberculosis, hepatitis $B$, measles, mumps, rubella, diphtheria, tetanus, pertussis, poliomyelitis and Haemophilus influenzae type B) (Table 5) (18).

All vaccines from the National Vaccination Schedule (18), including those intended for booster and catch-up immunization, are procured from state funds and are provided free-of-charge to children. All healthcare providers in Ukraine must have the relevant updated vaccine information materials and detailed instructions in Ukrainian, and provide these materials to parents upon request. Heads of all health facilities have the primary responsibility for ensuring compliance with this requirement. Detailed in-formation and instructions in Ukrainian for all vaccines registered in Ukraine can be viewed at http:// www.drlz.com.ua/.

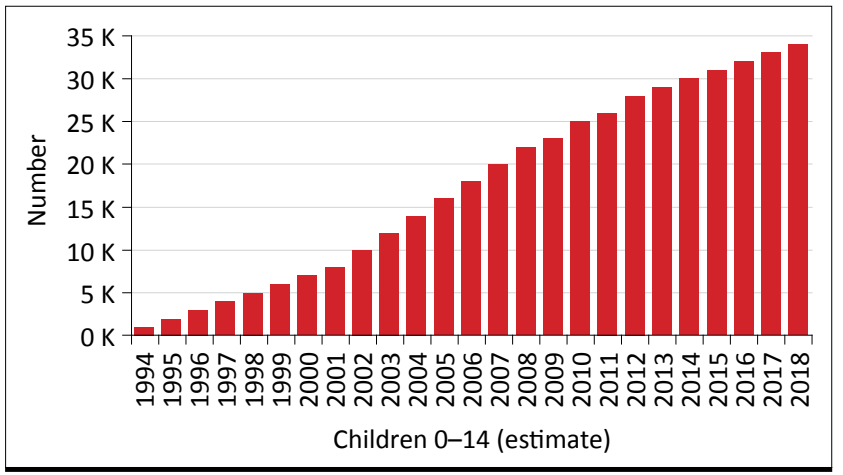

Figure 1. Number of HIV exposed children who are uninfected

In 2017, the percentage of births that received a dose of hepatitis B vaccine within 24 hours of delivery was $49 \%$, and the percentage of infants who received the third dose of hepatitis B containing vaccine following the birth dose was only $52 \%(19)$.

The tuberculosis incidence rate in Ukraine in 2016 was 67.6 per 100,000 persons - which, for perspective, is from ten to twenty times the rate in countries such as the United States of America, the United Kingdom or Canada (20). With support from WHO and international health partners, in 2018, Ukraine started implementing a new approach to tuberculosis control aimed at improving detection, treatment, and financing the fight against this disease. However, the percentage of births that received one dose of Bacillus Calmette Guerin (BCG) vaccine was 75\% in 2016 and 84\% in 2017, while the required minimum rate is $90 \%(19)$.

In recent years, there has been a shortage of measles vaccines in Ukraine. Vaccination rates had dropped to 31\% in 2016 and were the lowest in Europe. That is why in 2017-2018 over 12,000 people were infected with measles in Ukraine. Of those affected, 9158 required hospitalization and nine died, according to information provided by national health authorities as of April 2018 (21). 
The combined vaccine MMR vaccine is used against measles, mumps, and rubella in Ukraine. In 2017, MMR routine vaccination coverage almost doubled: $93.3 \%$ of children received the first MMR dose at the age of one, and $90.7 \%$ of children aged six years received the second dose (22).

In 2016 , only $3 \%$ of Ukrainian children were vaccinated against diphtheria, pertussis and tetanus during the first two years of life. Moreover, only $44 \%$ of children under 18 months of age were fully immunized against poliomyelitis (23).

Nowadays, the percentage of infants who received the first and third dose of diphtheria and tetanus toxoid with pertussis containing vaccine is $65 \%$ and $50 \%$, respectively (19).

In 2010, the WHO declared Ukraine a high-risk country for polio. In August 2015, the WHO was notified that circulating vaccine-derived poliovirus (cVDPV) had been identified in two unvaccinated Ukrainian children with paralysis. After this incident, three rounds of a nationwide vaccination campaign against poliomyelitis were organized in 2015-2016 with the international support of the Global Polio Eradication Initiative. The percentage of children vaccinated was $65 \%$ in round $1,75 \%$ in round 2 and $82 \%$ in round $3(24)$. However, routine vaccination against polio in Ukraine is still not effective. The percentage of infants who received three doses of polio containing vaccine (either oral or inactivated) has increased slowly, and in 2017 it was only 48\% (19).

Haemophilus influenzae type $b(\mathrm{Hib})$ conjugate vaccine was included in the national vaccination schedule of Ukraine in 2006. A follow-up national study revealed the dramatic effect this vaccine has on disease incidence and its high effectiveness at preventing bacterial pneumonia (25). However, the percentage of infants who received the full vaccination against Haemophilus influenzae type $b$ infection dramatically decreased from $83 \%$ in 2013 to $39 \%$ in 2017 (19).

In conclusion, data indicate that Ukraine is still suffering from a combination of factors affecting vaccination rates including public attitudes, systemic delivery problems, and Russian military intervention.

\section{Key messages and conclusions}

Positive developments in Ukrainian undergraduate medical education include Erasmus student academic mobility programs, and at postgraduate levels increased participation in international medical observerships and fellowships, and medical online education programs help our professionals participate in and contribute to European medical knowledge. Despite the improvement in the recent quality of pediatric care, the sociodemographic situation is precarious due to the negative annual growth rate of the population and the decrease in the population aged 0-14 years. Many children with inherited disorders were diagnosed in time, but it is necessary to introduce neonatal screening for galactosemia, lysosomal storage disorders, and other disorders. Reforming the public health system has been challenging and has not been effective. This is why our country has the highest incidence HIV in Eastern Europe and Central Asia, and the percentage of infants who received the full vaccination against the 10 main infections (according National Vaccination Schedule) is low. Improved knowledge of HIV prevention among young people and an increase in parent compliance with vaccination are major tasks for national public health.

Conflict of Interest: The author have no conflicts of interest to declare.

Financial Disclosure: The author declared that this study has received no financial support.

\section{References}

1. United Nations. Ukraine: Country Overview. Available at: http://www.un.org.ua/en/country-team-in-ukraine/ ukraine. Accessed November 1, 2019.

2. Decentralizaion. About amalgamation of hromadas. Available at: https://decentralization.gov.ua/en/gromadas. Accessed November 1, 2019.

3. Wikipedia. Demographics of Ukraine. Available at: https:// en.wikipedia.org/wiki/Demographics_of_Ukraine. Accessed November 29, 2018.

4. The World Bank. World Bank national accounts data. Available at: https://data.worldbank.org/indicator/NY.GDP. PCAP.CD?year_high_desc=true. Accessed July l, 2018.

5. WHO. Evaluation of structure and provision of primary care in Ukraine. A survey- based project in the regions of Kiev and Vinnitsa. Available at: http://www.euro.who. int/_data/assets/pdf_file/0016/129022/e94565.pdf.

6. Government Portal. National Health Service of Ukraine. First reports on its activities and identifies top five most active regions. Available at: https://www.kmu.gov.ua/ en/news/moz-yaki-regioni-stali-liderami-za-viplatami-vid-nacsluzhbi-zdorovya.

7. UNICEF Ukraine. Breast-feeding: a Woman's Happiness, a and Society's Maturity Test. Available at: https://www. unicef.org/ukraine/reallives_12917.html.

8. The World Breastfeeding Trends Initiative (WBTI). Ukraine assessment report, 2015. Available at: http:// worldbreastfeedingtrends.org

9. UNICEF. Press centre. Media advisory. UNICEF Exec. Dir. to visit Ukraine to focus on HIV/AIDS and Iodine 
deficiency Disorders. Available at: https:// www.unicef. org/media/media_2084.html. Accessed July 06, 2020.

10. Index Mundi. Infant mortality rate. Available at: https:// www.indexmundi.com/g/g.aspx?c=up\&v=29. Accessed November 1, 2019.

11. Knoema. World and regional statistics. Ukraine - Under-five mortality rate. Available at: https://knoema.com/ atlas/Ukraine/Child-mortality-rate?origin=knoema.ru\&_ ga=2.114549248.62459676.1543478321-62690718.1543478321.

12. Knoema. Ukraine - Neonatal mortality rate.Available at: https://knoema.com/atlas/Ukraine/Neonatal-mortality-rate.

13. UNICEF Ukraine. Ukraine at a glance. Politics on women and children. Available at: https://www.unicef.org/ ukraine/about.html.

14. UNICEF Ukraine. Ukraine Humanitarian Situation Report n.42. Available at: https://reliefweb.int/ report/ukraine/ukraine-humanitarian-situation-report-42-1-31-january-2016.

15. UNICEF Ukraine. 430,000 children continue to bear the brunt of eastern Ukraine conflict. Available at: https:// www.unicef.org/ukraine/en/press-releases/ 430000-children-continue-bear-brunt-eastern-ukraine-conflictunicef. Accessed July 07, 2020.

16. UNAIDS. Ending AIDS: Progress towards the 90-90-90 targets. Global AIDS Update; 2017. 198 p. Available at: https:// www.unaids.org/en/resources/documents/2019/2019-global-AIDS-update. Accessed November 1, 2019.

17. Unaids. Country factsheet: Ukraine 2018. Available at: http://www.unaids.org/en/regionscountries/countries/ ukraine. Accessed July 06, 2020.

18. Ministry of Health of Ukraine. National Immunization Schedule. Available at: http://en.moz.gov.ua/vaccinations.
19. WHO. Ukraine: WHO and UNICEF estimates of immunization coverage: 2017 revision. http://www.who.int/ immunization/monitoring_surveillance/data/ukr.pdf. Accessed November 1, 2019.

20. United Nations Ukraine. World TB Day 2017: Timely TB identification and treatment are essential for successful recovery. Available at: http://www.ua.undp.org/content/ ukraine/en/home/presscenter/pressreleases/2017/03/22/ world-tb-day-2017-access-to-treatment-is-key-to-leaving-no-one-behind.html. Accessed March 22, 2017.

21. WHO Europe. Ukraine restores immunization coverage in momentous effort to stop measles outbreak that has affected more than 12000 this year. Available at: http://www.euro.who.int/en/countries/ukraine/news/ news/2018/05/ukraine-restores-immunization-coveragein-momentous-effort-to-stop-measles-outbreak-thathas-affected-more-than-12-000-this-year. Accessed May 4, 2018.

22. UNICEF. UNICEF and the Ministry of Health bring a new consignment of measles vaccine to Ukraine. Available at: https://www.unicef.org/ukraine/media_31791. html. Accessed February 2, 2018.

23. UNICEF. Increasing immunization coverage is priority for Ukrainian Government - Vice Prime Minister of Ukraine. Available at: https://www.unicef.org/ukraine/ media_29789.html. Accessed October 24, 2016.

24. UNICEF. Polio Outbreak in Ukraine, 2015-2016. Unique Challenges, Comprehensive Response. Kyiv, Ukraine: UNICEF Ukraine Country Office; 2016.p.60.

25. Pilishvili T, Chernyshova L, Bondarenko A, et al. Evaluation of the effectiveness of Haemophilus influenzae type b conjugate vaccine introduction against radiologically-confirmed hospitalized pneumonia in young children in Ukraine. J Pediatr 2013; 163: S12-8. [CrossRef] 